\title{
Runic Spindle Whorl Recently Found in Orkney
}

\author{
Ragnhild Ljosland (University of the Highlands and Islands) \\ With a contribution by Gail Drinkall (Orkney Museum)
}

\begin{abstract}
This article gives an account of a rune-inscribed bone spindle whorl which was found by a member of the public in Orkney in January 2017. The inscription will presumably be designated as OR 24 . The circumstances of the find are briefly discussed and the artefact described and depicted. Thereafter follows a transliteration and commentary on the reading and an interpretation of the text, which seems to be a futhark inscription with some notable oddities.

Along with the spindle whorl bearing OR 24, the finder also handed in a quartzite pebble from the same site, which is decorated with a painted runelike mark. The article discusses whether the painted mark is intended as a rune, and whether the artefact is Norse at all. The conclusion is that the mark is most probably not intended to be runic and that the artefact is likely to be Pictish rather than Norse.
\end{abstract}

Keywords: spindle whorl, Orkney, futhark inscription, bone, quartzite pebble

\section{Introduction: finds and site}

$\mathrm{T}$

wo interesting artefacts from the same site in Orkney were found in early January 2017: a rune-inscribed bone spindle whorl (fig. 1) and a painted pebble (fig. 8). These artefacts were both found in spoil and handed in on 9 January 2017 by a member of the public who had been out walking through an area mined for sand on the island of Burray in the vicinity of grid reference ND 48439, 97919. The finder brought the two artefacts in with more bones, bone fragments and shells, all originating from the same site but bearing no trace of paint or carving. Most interestingly, among these non-inscribed objects was also a second spindle whorl, identical to the rune-inscribed whorl but lacking an inscription. The finder alerted the

Ljosland, Ragnhild. "Runic Spindle Whorl Recently Found in Orkney."

Futhark: International fournal of Runic Studies 9-10 (2018-2019): 215-229.

DOI: $10.33063 /$ diva-401055

(C) 2020 Ragnhild Ljosland (CC BY) 
University of the Highlands and Islands and the Orkney Museum to the discovery. The present author examined both artefacts at the Archaeology Institute of the university, using a stereo microscope, in January 2017 while awaiting a decision on Treasure Trove.

The area where the objects were found is known as a multi-period site, having previously yielded prehistoric, Iron Age/Pictish and Norse material. Artefacts of particular beauty and interest are the "Peedie Pict", a human figure wearing a thigh-length tunic carved on the phalanx of an ox, and four antler pieces decorated with lines and ring-and-dot motifs, which could date from any time between the beginning of our time-reckoning and the 1200s (Lawrence 2005). Nevertheless, the area is not recognised by the general public as a site notable for archaeological interest and is not among Orkney's visitor attractions.

The site is predominantly sandy and affected by coastal erosion. It has also been greatly disturbed by modern activity, having for many years been used for commercial sand extraction. In this process, sand is industrially sieved and the residual material dumped in refuse piles. It is my understanding from speaking with the finder that the artefacts were found in one of these refuse piles. The assemblage must therefore be regarded as unstratified but not an isolated find. It is thus now impossible to determine if the two bone spindle whorls are associated; they may be unrelated (Julie Gibson, Orkney County Archaeologist, pers. comm., 19 Jan. 2017). This also means that the artefacts were not exposed for long and were in all probability preserved in sand until relatively shortly before their discovery.

The preservation conditions for bone are generally favourable in Orkney in sandy ground, and archaeological excavations in similar environments have uncovered well-preserved bone artefacts. For example, an assemblage of 561 bone tools and tool fragments dating from the Neolithic to the early Iron Age were found in good condition at Tofts Ness on the island of Sanday, some of which bore finely cut marks (Dockrill et al. 2007, 170, 325). At the Links of Noltland in Westray - a similarly sandy, coastal site - animal bone material was also found "in excellent condition" (Moore and Wilson 2011, 41).

Comparable to the painted pebble, preserved prehistoric paint also occurs on stone elsewhere in Orkney. Yellow, red and brown pigment was identified at the Neolithic site of Ness of Brodgar (Thomas 2016, $134 \mathrm{f}$.). Pebbles similar to this one, with decoration in brown pigment, have been found in archaeological excavations at Buckquoy (Ritchie 1976-77, 197), Howe (B. Smith 1994, 192) and Burrian (Sharples 1998, appendix 2). 

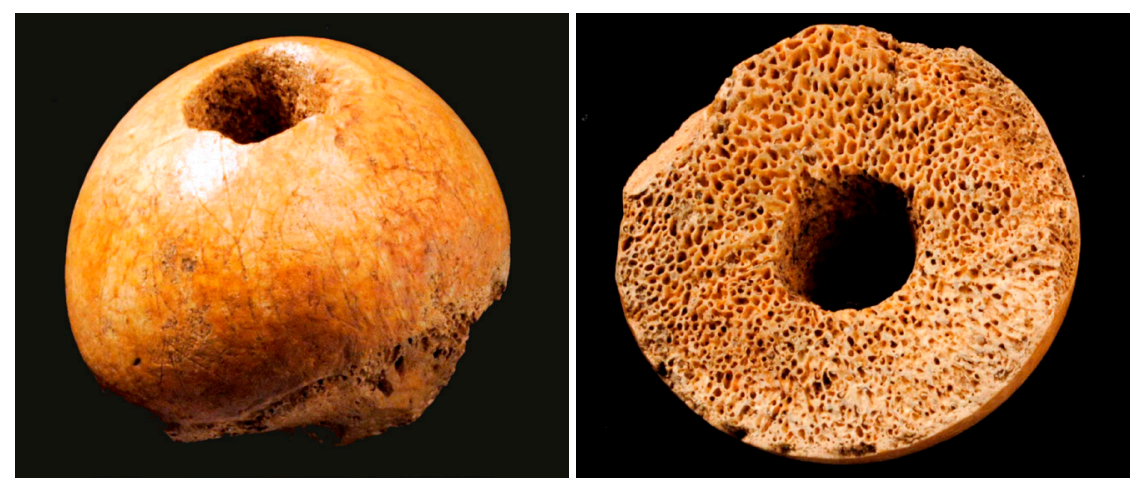

Fig. 1. The runic bone spindle whorl, $a$ (left) outer face, $b$ (right) cut face. Photo: Orkney Museum, () Orkney Arts, Museums and Heritage.

The rune-inscribed spindle whorl will in the following be described in some detail and a reading and interpretation of its inscription (OR 24) will be given. Thereafter, the painted pebble will be considered.

\section{OR 24 Burray runic spindle whorl}

The inscription OR 24 is on a bone spindle whorl which was after initial examination by Orkney County Archaeologist Julie Gibson determined to be made from a cow's femur (fig. 1 a). It is in the shape of a hemisphere, with the inside bone structure visible where it has been cut away from the rest of the bone (fig. $1 b$ ) while the curved outer surface has a smooth, polished appearance. The maker has chosen to use the natural hemisphere of the head of the femur to create the utensil. The maximum diameter of the spindle whorl at its base is $40 \mathrm{~mm}$, and the height $23 \mathrm{~mm}$ though incomplete. The femur is perforated by a hole which has been drilled from both sides, measuring $10 \mathrm{~mm}$ in diameter.

The whorl has indeed been used for spinning (Gail Drinkall, Curator of Archaeology, Orkney Museum, pers. comm., 9 Feb. 2018), as the smooth outer surface shows signs of wear and contains a myriad of small cracks and lines in addition to the deliberately incised runes. The runes, which run around the entire circumference, will be described in more detail below.

In overall appearance, the spindle whorl strongly resembles medieval Norse examples found in the excavation at Quoygrew, Westray, Orkney, which were also made from femur heads (Ashby 2012, 242). Spindle whorls made from the head or caput of a femur usually, but not exclusively, 


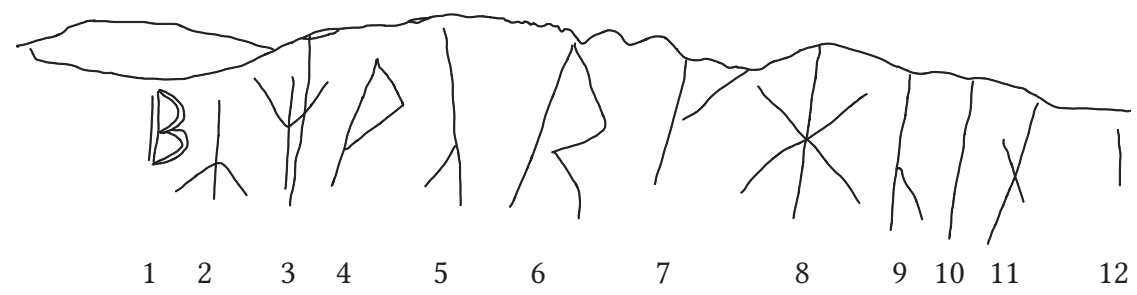

Fig. 2. The author's free-hand sketch showing a flattened view of the inscription, necessarily distorted by the linear presentation of a hemisphere

bovine are known from the British Iron Age (ending A.D. 100) onwards but enjoyed a renewed burst of popularity from the 800 s to the $1100 \mathrm{~s}$ (MacGregor 1985, 187). The type and form of the whorls themselves, however, cannot be used as a chronological indicator; only when found in secure archaeological contexts can they be dated. In Orkney, excavations at the multi-period site of Pool on the island of Sanday did not produce femur head whorls until phase 6.4, calibrated to 210-660 AD (A. Smith 2007, 498 f.), while at Quoygrew, Westray they occur in deposits from the 1200 s to the 1500s (Batey 2012, 242). Further afield, at Coppergate in York, thirty-six of the fifty-four femur head spindle whorls came from AngloScandinavian deposits dating from the mid- to late 900 s to mid- to late 1000 s, the remainder being derived from contexts from the 1100 s to the late 1400s (Walton Rogers 1997, 1741). ${ }^{1}$

\section{Reading of the Inscription}

The outer surface of the whorl on which the runes are carved has a circumference of around 125 millimetres at the broad end. The tops of the runes are located at this end, which is closest to the cut, straight face, while the bases of the runes are located at the narrower end, near the edge of the perforation.

The twelve runes are made by relatively shallow cuts with a sharp finepointed instrument, perhaps a knife blade, and, with the exception of rune 1 , in single cuts. The staves vary in height from 11 to $28 \mathrm{~mm}$. The tops of the staves are all close to the top edge, with $3 \mathrm{~mm}$ as the greatest distance from the edge. The bottoms of the staves end at a distance varying from 0 to $12 \mathrm{~mm}$ from the perforation.

${ }^{1}$ This paragraph, from "Spindle whorls made from" onwards, is a contribution by Gail Drinkall, Curator, Orkney Museum. 
The runes follow the curved surface around the whorl, necessitating an angle between the staves of neighbouring runes: as the whorl is narrower at the bottom than the top (i.e. the flat, cut end), the staves cannot all be truly parallel if they are to continue evenly around the circumference. The maximum distance from one stave to the next measured at the top is $23 \mathrm{~mm}$ and at the bottom $11 \mathrm{~mm}$. The significance of this will become apparent in the discussion below of rune 8 .

The runes are in the younger futhark, of the type commonly found in Norway (Barnes 2012, 62, fig. 17); see runes 3, 9 and 12 in particular. The runes of OR 24 have been transliterated below in accordance with the principles given in Barnes 2012. A space where no runes are clearly decipherable is marked by ..., countable but unidentifiable runes by an asterisk, and tentative identification (i.e. uncertain reading) is shown by round brackets.

As the inscription extends around the circumference of the spindle whorl, it is not immediately apparent where to begin reading. There is, however, a $\mathbf{b}$ which has been very deliberately cut with double lines (thanks to Julie Gibson for passing on this observation). This technique brings to mind the double lines of OR 11 on an inscribed bear's tooth from the Brough of Birsay. The $\mathbf{b}$ is preceded by a $13 \mathrm{~mm}$ space where the surface is very worn and in which there may or may not have been a further rune (see below for discussion of a possible stave 13 here). In the absence of any other clues as to where to commence reading, this $\mathbf{b}$ has been chosen as a starting point.

The transliteration of the inscription is as follows (cf. fig. 2, a free-hand sketch by the author of the inscription):

\section{...bymp(o)rkhnin(s)}

$1 \quad 5 \quad 10$

Initially, however, it would be prudent to emphasise the general uncertainty that must attach to any reading of the runes due to their very fine lines and the overall wear and tear on the surface of the object.

The stave of rune 1 (see figs 3 and 7) is at $12 \mathrm{~mm}$ the shortest full stave. Both stave and pockets of the $\mathbf{B} \mathbf{b}$ (the upper not as clearly) are cut with double lines.

Rune 2 (see fig. 3) measures $16 \mathrm{~mm}$ and has two branches extending downwards from either side of the stave from a point $5 \mathrm{~mm}$ above the base. In accordance with the Norwegian "mixed" younger futhark (Barnes 


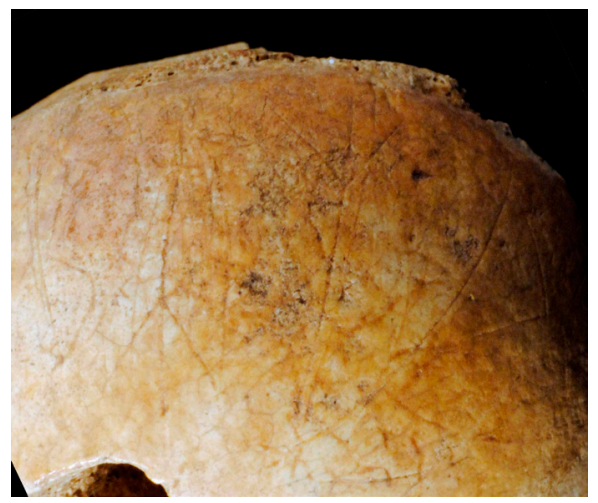

Fig. 3. Detail of the spindle whorl showing runes 1-4/(5). Photo: Orkney Museum, () Orkney Arts, Museums and Heritage.

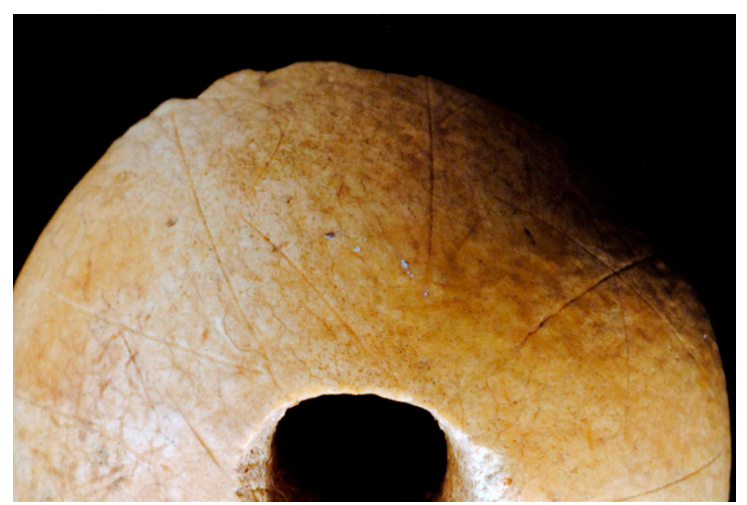

Fig. 4. Detail of the spindle whorl showing runes 5-8. Photo: Orkney Museum, () Orkney Arts, Museums and Heritage.

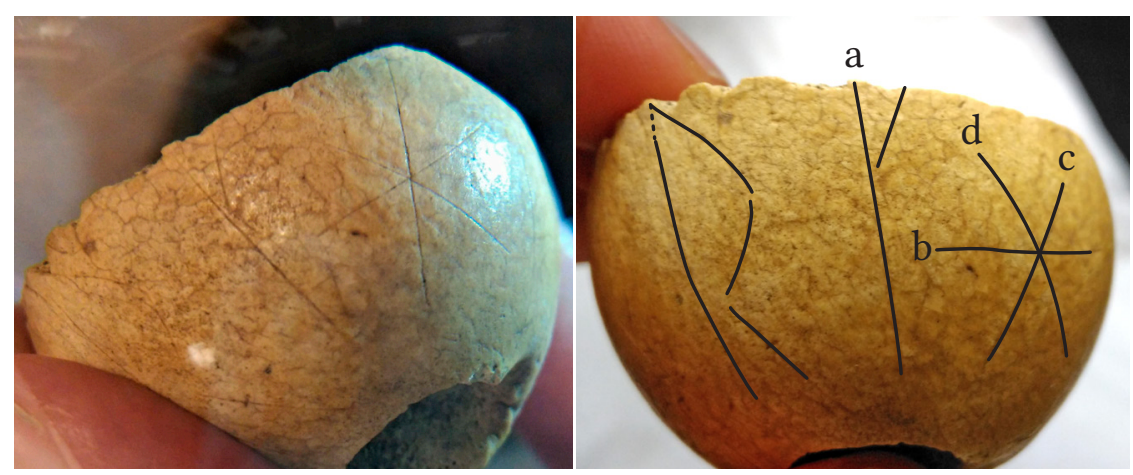

Fig. 5. The spindle whorl, $a$ (left), showing runes (6)/7-8; $b$ (right) runes $6-8$, enhanced. Photos and enhancement: Ragnhild Ljosland. 


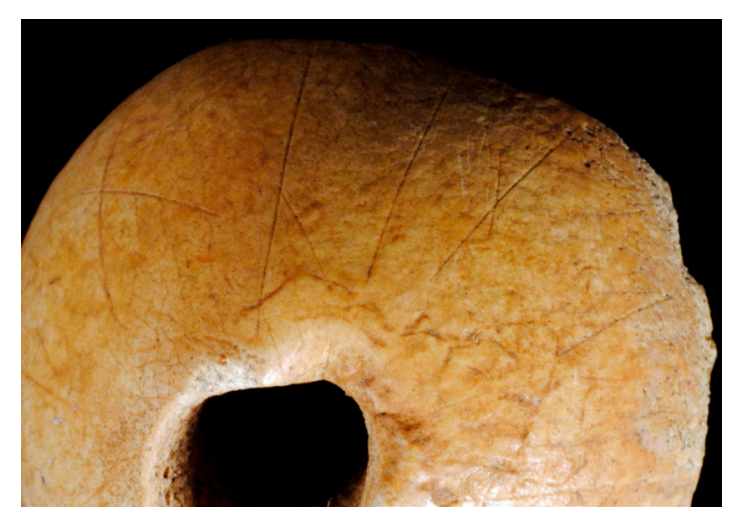

Fig. 6. Detail of the spindle whorl showing runes 8-12. Photo: Orkney Museum, ( ) Orkney Arts, Museums and Heritage.

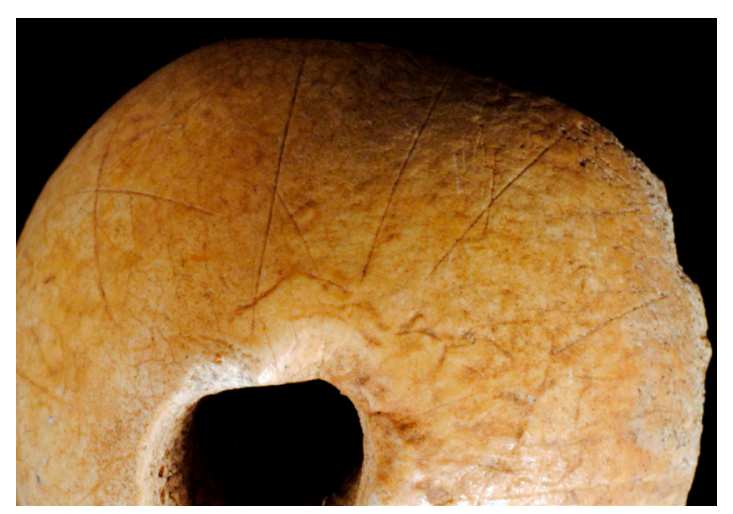

Fig. 7. Detail of the spindle whorl showing runes $10-12$ and 1 , and in addition a line between runes 12 and 1, which may be the remains of a further stave. Photo: Orkney Museum, $\odot$ Orkney Arts, Museums and Heritage.

2012, 62) and the Maeshowe inscriptions (Barnes 1994), this rune has been transliterated as $\lambda \mathbf{y}$.

Rune 3 is $19 \mathrm{~mm}$ tall and has two branches extending upwards, one on either side of the stave and connecting with the stave $6 \mathrm{~mm}$ from the top, thus $Y \mathbf{m}$.

Rune 4 has a $16 \mathrm{~mm}$ tall stave with a pocket spanning $11 \mathrm{~mm}$ from top to bottom. The bottom stroke of the pocket is easier to discern than the top stroke, but both are visible through a stereo microscope. The top stroke of the pocket connects with the stave at the top edge of the worked surface of the whorl, but it is possible that some of the surface has been lost here so that the stave of the $\mathbf{P} \mathbf{p}$ may once have extended further. 
On rune 5 (see fig. 4) a branch extends down to the left $18 \mathrm{~mm}$ from the top of a $28 \mathrm{~mm}$ tall, shallow-cut stave. The low-set position of the branch would allow for a second branch above it, thus possibly $\neq$, although in its current worn state a second branch is difficult to trace with certainty. This rune has therefore been transliterated as (o).

Rune 6 is an $R \mathbf{r}$ with a clearly visible pocket and branch. The stave is $24 \mathrm{~mm}$ tall.

Rune 7 has a branch extending upwards to the right; this does not fully connect with the stave, which measures $16 \mathrm{~mm}$, but there is little doubt that this is meant as $Y \mathbf{k}$.

A point of particular interest is the execution of rune $8, \boldsymbol{W} \mathbf{h}$ (see fig. 5 a), and it will therefore be discussed at some length. Its two branches are long, in fact similar in length to the stave. For ease of reference, each of its three strokes has been enhanced and labelled as $b, c$, and $d$ in fig. $5 b$. Of the three strokes, $c$ is the longest at $20 \mathrm{~mm}, d$ is $17 \mathrm{~mm}$ and $b 16 \mathrm{~mm}$. The stave of its left neighbour, rune $7 \mathrm{Y}$ k (marked in fig. $5 b$ as stroke $a$ ), stands at a $32^{\circ}$ angle to stroke $c$ in rune 8 . Although this is a large angle, it is not unique in the inscription; compare for example the $30^{\circ}$ angle between the staves of runes 5 and 6.

The angle and stroke lengths raise the question of which stroke is intended as the stave of rune 8. Being marginally longer than the other two, stroke $c$ may be interpreted as the stave. The $32^{\circ}$ angle may be explained by the curving of the surface, which necessitates a certain angle between staves in any case. The interpretation of stroke $c$ as the stave is strengthened by the fact that $c$ and the stave of rune 9 on its right are nearly parallel, set at a distance to each other of $10 \mathrm{~mm}$ at the top and $8 \mathrm{~mm}$ at the bottom of the stave.

Alternatively, stroke $b$ might be interpreted as the stave of $\mathbf{h}$, but if so, we would be dealing with a horizontal stave. Stroke $b$ is almost perpendicular to $a$, the potential implications of which will be discussed below. The reading of rune 8 as $\mathbf{h}$ is nevertheless unproblematic.

Rune 9 (see fig. 6) has a $17 \mathrm{~mm}$ tall stave and a single branch extending downwards to the right and connecting with the stave $9 \mathrm{~mm}$ from the top, thus $\mathbf{n}$.

There are no visible traces of a branch on rune 10 , only a clear $16.5 \mathrm{~mm}$ tall stave and thus $\mid \mathbf{i}$.

Rune 11 (see figs 6-7) has a branch which crosses the stave downwards from left to right, as for a long-branch $\mathbf{n}(\dagger)$, meeting the stave $8.5 \mathrm{~mm}$ from the top. The branch is clear on the left-hand side, but less clearly intentional and also shorter on the right. This has been transliterated as $\mathbf{N}$ to signal the varying form, different to rune 9. 
Rune 12 occurs in a worn area and consists of a vertical stroke $11 \mathrm{~mm}$ in length, finishing $12 \mathrm{~mm}$ above the perforation, which may be interpreted as ' $\mathbf{s}$.

There are no clear remains of further runes between 12 and 1 ; however, this area is worn and there is a very faint vertical line $8 \mathrm{~mm}$ to the right of rune 12, which may or may not be the remains of a further stave ${ }^{2}$ (fig. 7). If it were to be interpreted as a stave, one would expect it to be that of a t. Between this faint line and rune $1, \mathbf{b}$, there is a space of only $4 \mathrm{~mm}$, something that would fit well with a preceding $t$-rune with no branches to the right, 1 .

\section{Discussion and interpretation}

The transcription of the text is as follows: ...bymp(o)rkhnis(s)

The overall interpretation of the inscription seems reasonably straightforward: It is a futhark inscription, albeit missing some characters and with others in an unexpected order. The sequence $\mathbf{p}(\mathbf{o}) \mathbf{r k h n i}$ (runes 4-10) should make this interpretation reasonably certain.

As an unstratified find from a multi-period site, it is difficult to determine the age of the artefact and inscription. The hemispherical shape is fairly typical of Norse spindle whorls; see Ashby (2012, 229-44) for examples from Orkney. The difficulty is narrowing the time frame to the Viking Age or the Scandinavian Middle Ages, or further within these periods. Radiocarbon dating of the bone material has not been attempted and is unlikely to yield much information because the calibration curves are too flat in that time period and can thus provide only very broad datings. Chemical analysis of the bone in order to determine the cow's diet and possible exposure to radiation could possibly reveal a modern origin. Such analysis has, however, not been undertaken.

Comparable to the text of the Burray spindle whorl are two other futhark inscriptions from Orkney (OR 11 and OR Barnes 6), and comparable to the artefact type is one other rune-inscribed spindle whorl (OR 3).

The spindle whorl, OR 3, reads (Barnes and Page 2006, 158, where ï signifies a dotted $i$-rune):

$* * \mathbf{k a} * * * \mathbf{r}(\mathbf{r}) \ddot{i s} * \mathbf{r u n} * *$

... reis[t] rún[ar]

${ }^{2}$ Thanks to Michael P. Barnes for his observations after a brief inspection of the artefact in September 2019 regarding a possible stave 13 (transmitted in an e-mail of 26 Sept. 2019 to James Knirk). 
The provenance of the spindle whorl is unfortunately not known. It was bought in Stromness in 1896 but was said at the time to hail from Shetland. This would tally with the material, steatite, which is found naturally in Shetland but not in Orkney.

The two futhark inscriptions from Orkney read:

\section{OR 11: fupork*}

\section{OR Barnes 6: fuporkhniastbynu}

OR 11 is on a bear's tooth from the multi-period Pictish/Norse site called the Brough of Birsay (Barnes and Page 2006, 187-91). Its runes are cut with double lines like the $\mathbf{b}$ of OR 24 , and the tooth is perforated at one end, presumably for suspension. Barnes and Page (p. 191) tentatively date it to the 800 s or 900 s, although it is "not impossible" that it may be as late as the 1100s. OR Barnes 6 is one of the Maeshowe collection of inscriptions from the 1100s carved on the inside walls of a Neolithic tomb (Barnes 1994, 79-81). Interestingly, this futhark also contains the sequence by, but one should perhaps not overemphasise this connection, as mistakes near the end of the futhark are somewhat common.

The runes in OR 24 appear largely as expected in a medieval context from Orkney, in keeping with for example the Maeshowe collection; unfortunately they include no dotted runes, which could have supported the hypothesis of a medieval (that is post-Viking Age) origin.

Double lines, as seen in rune $1, \mathbf{b}$, were according to Barnes and Page $(2006,191)$ most common in mainland Scandinavia in the 1100s and 1200s, although not unknown earlier.

One rune that may offer a clue to the age of the inscription is rune 8 , $\mathbf{h}$ (see fig. 5). As noted above, the three strokes are of roughly equal length. This variant of $\boldsymbol{h}$, i.e. with lengthened branches, is common in the relatively late runic tradition of Iceland; Bæksted $(1942,41)$ notes that "former med særlig lange, evt. krumme bistave betegner uden tvivl yngre typer". This innovation in the shape of $\mathbf{h}$ is first recorded in IS IR;147 Höskuldsstaðir, dated to 1383 or shortly thereafter.

The majority of occurrences of this type of $\boldsymbol{h}$ date from the 1400 s to the 1600 s in the late Icelandic runic tradition. Good examples are two gravestones from Eyvindarmúli: IS IR;87B 1 (dated by Bæksted to 1500-1600), and IS IR;89. The informal IS IR;90 in Paradísarhellir contains further examples: both text 3 , hallr, and text 14, hier:kom:sira:steinmadr, evidence $\mathbf{h}$ with lengthened branches, though the dating of individual inscriptions on the rune-covered natural rock surface in the cave is uncertain. A casually 
carved runic alphabet in Roman alphabet order, IS IR;158, on a chair from Grund in the county Eyjafjarðarsýsla dated to 1551, also includes an $\mathbf{h}$ with very long branches. Good examples from the 1600 s include the grave stone IS IR;86 Teigur 1 (from 1600-1650), and the fragment IS IR;87A Teigur 2, which shows $\mathbf{h}$ with lengthened branches between framing lines. Also from the 1600s are IS IR;145 and IS IR;146, both from Holt. (See the plates in Bæksted 1942 for photographs of all of these inscriptions.)

As regards the remote possibility that the stave of $\mathbf{h}$ in OR 24 may in fact be horizontal (i.e. stroke $b$ ), there are two early modern Icelandic parallels: on the grave slab IS IR;133 from Breiðabólstaður, dated 1681, and in a manuscript from the 1600s, AM 193, IV 8vo (Bæksted 1942, 41). This type of $\mathbf{h}$ with horizontal stave also occurs twice in IS IR;111 on the lost grave prism from Hvammur (also known as Hvammur 1), dated in the Scandinavian Runic Text Database (Samnordisk runtextdatabas) to the medieval period. The drawing reproduced in Bæksted 1942 shows that the horizontal stave is in both instances here shorter than the two branches.

Relevant also is IS IR;207B, a spindle whorl from Stóramörk bearing the text: mariafuporkhniastbmly. The $\mathbf{h}$ has long branches although the stave is marginally longer than either branch.

Despite the shape of the $\mathbf{h}$, however, there are problems with interpreting the runes of OR 24 as showing Icelandic influence. Although $\mathbf{h}$ appears possibly to be of an Icelandic type, the $\mathbf{s}$ (rune 12) and $\mathbf{y}$ (rune 2) do not. Icelandic $\mathbf{s}$ is full height, often with a large circle or lozenge shape at the bottom which is sometimes cut through by the stave. Rune 12 in Or 24, which may be read as $\mathbf{S}$, shows none of these characteristics: it is not full height and lacks a point, circle or lozenge. The surface of the spindle whorl is rather worn here, however, so parts of the rune might have worn away.

Rune $2, \mathbf{y}$, is however much clearer. This rune is of the Norwegian type, $\lambda$, and not the Icelandic type $\mathfrak{I}$ (see Bæksted 1942, 50, for a table comparing Norwegian and Icelandic rune forms). It may therefore be advisable not to overstate the connection with Iceland that rune $8 \mathbf{h}$ seems to suggest.

\section{The painted pebble}

The second find from Burray is a small, quartzite pebble with an almost perfectly circular circumference, $26.5 \mathrm{~mm}$ maximum diameter and $13 \mathrm{~mm}$ high.

In size, shape, stone type, dye, and general appearance, the artefact strongly resembles the fifty-five Pictish painted pebbles that have been 

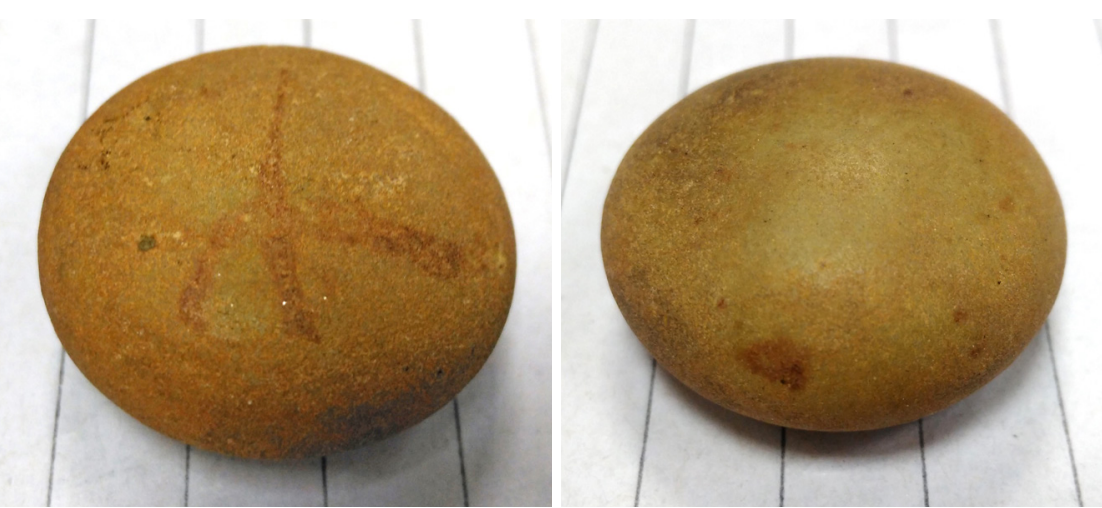

Fig. 8 . The painted pebble, $a$ (left) side 1 , with paint; $b$ (right), side 2. Photos: Ragnhild Ljosland.

found at broch sites and post-broch sites in Scotland, often within secondary phase activity at broch sites. This artefact type is particularly prominent in Shetland and Caithness. Five Pictish painted pebbles have previously been found in Orkney, from Iron Age and Pictish contexts, one at Buckquoy (Ritchie 1971, 300; 1976-77, 199), three at the Broch of Burrian, North Ronaldsay (Ritchie 1971, 300 f.), and one at Howe, Stromness (Arthur, Murray, and Ritchie 2014, 13-16).

The painted mark on one main surface of the newly found pebble from Burray (fig. 8 a) resembles a runic $\psi$ or $\alpha$, with a "stave" and two "branches" extending on either side. As with the aforementioned Pictish painted pebbles, the design is painted using an indeterminable dye, of which a dark brown stain now remains. There is also a visible dot on the edge of the opposite surface (fig. 8 b), and slightly uneven colouring on this surface may indicate that it once had further painted marks on this side (Julie Gibson, pers. comm., 19 Jan. 2017).

The main mark's resemblance to a rune is most likely coincidental. Pictish painted pebbles commonly bear designs consisting of dots and wavy lines. The painted design on the Burray pebble closely resembles a Pictish painted pebble from Udal, North Uist. Described as a "saltire" motif (Arthur, Murray, and Ritchie 2014, 6), the Udal pebble's design has two crossed lines perpendicular to each other, flanked by a dot in each resulting quadrant. Compared to the Udal pebble, the Burray pebble might be said to show a similar "saltire" except that the second line is curved, thus causing the resemblance to the two branches of the $\psi$ or $h$ rune. As on the Udal pebble, the Burray pebble's two lines intersect close to, but very 
slightly offset to, the middle of the "stave" line. The Burray pebble now has only one remaining, visible dot; this is positioned differently to the dots on the Udal pebble but the dot motif is nonetheless present. There is also a similarly decorated pebble from Howe near Stromness, Orkney, currently in the Orkney Museum. The Howe pebble has one broad stroke across it flanked by four dots.

The site in Burray where the painted pebble was found has previously yielded both Pictish and Norse material (Lawrence 2005), so as an unstratified find it is not possible to tell from the find site alone whether we are dealing with a Pictish painted pebble, a Norse runic pebble, or even a modern fabrication. However, the improbability of someone placing a modern imitation on an industrial site, rather than at one of Orkney's many famous archaeological attractions, speaks against a modern origin. Furthermore, the mineral, size, shape, pigment and decoration, all bearing strong resemblances to the characteristics of Pictish painted pebbles found in secure archaeological contexts, suggest that the Burray pebble is indeed another Pictish painted pebble and not a Norse runic or modern product.

\section{Conclusions}

As regards OR 24 on the runic spindle whorl, the present author feels confident concluding that the runic inscription is genuine. There is some uncertainty regarding its interpretation but it is most likely an attempt at a futhark inscription. It is however unusual in futhark inscriptions to misrepresent the beginning of the rune-row. It is of course not easy to discern where a circular inscription begins, but if we assume that runes $1-3$, bym, represent the ending (where we would expect bmly), then the beginning must be runes $4-7$, pork. We are therefore left in the strange circumstance of seeing a futhark where the expected first two runes, fu, are entirely missing. Another noticeable feature is the double-cut $\mathbf{b}$ (rune 1), although it is difficult to ascertain whether the doubling of the lines carried any meaning for the carver, and to comprehend why $\mathbf{b}$ has been thus singled out. It would be easy to envisage an embellished initial letter, and if one chooses not to see the potential stave 13 as intentional then the b does indeed appear after an apparently slightly larger gap and could as such be interpreted as the "first" letter of a circular text. However, this interpretation is complicated by the peculiar absence of $\mathbf{f u}$.

The dating of the inscription is uncertain but somewhere within the medieval period seems a reasonable guess, and from the shape of the $\mathbf{h}$ 
potentially late medieval. The lengthened branches of the $\mathbf{h}$ might suggest contact with Iceland, although $\mathbf{s}$ and $\mathbf{y}$ do not appear in their Icelandic forms.

As regards the painted pebble, the conclusion is that despite the main mark's close resemblance to a runic character, the design is not runic and the rune-like shape of the painted mark is merely coincidental. It is most likely Pictish and dates to the centuries preceding the Norse settlement of Orkney. This conclusion was reached after consideration of the Burray pebble's strong parallels to other Pictish painted pebbles and the recorded presence of other Pictish finds from the same site. ${ }^{3}$

\section{Bibliography}

Arthur, Robbie, Jenny Murray, and Anna Ritchie. 2014. "ARO12: Painting the Stones Black: Solving the Mystery of Painted Quartz Pebbles.” Archaeology Reports Online 12. http://archaeologyreportsonline.com/reports/2014/ARO12. html (accessed 24 March 2017).

Ashby, Steve P. 2012. "Evidence of Exchange Networks: The Combs and Other Worked Skeletal Material." In Being an Islander: Production and Identity at Quoygrew, Orkney, 900-1600, ed. James H. Barrett, 229-39. Cambridge.

Barnes, Michael P. 1994. The Runic Inscriptions of Maeshowe, Orkney. Runrön, 8. Uppsala.

- 2012. Runes, a Handbook. Woodbridge.

Barnes, Michael P., and R. I. Page. 2006. The Scandinavian Runic Inscriptions of Britain. Runrön, 19. Uppsala.

Batey, Colleen. 2012. "Other Worked Skeletal Material." In Being an Islander: Production and Identity at Quoygrew, Orkney, 900-1600, ed. James H. Barrett, 240-43. Cambridge.

Bæksted, Anders. 1942. Islands runeindskrifter. Bibliotheca Arnamagnæana, 2. Copenhagen.

Dockrill, Stephen J., with Julie M. Bond and Andrea N. Smith. 2007. Tofts Ness, Sanday: An Island Landscape through 3000 Years of Prehistory. Vol. 2 of Investigations in Sanday, Orkney. Kirkwall.

IS IR + no = inscription from Iceland published in Bæksted 1942 (siglum from the Scandinavian Runic Text Database).

\footnotetext{
${ }^{3}$ The author would first like to thank the finder very much for turning in the runic spindle whorl and painted pebble. I would also like to thank Julie Gibson, Gail Drinkall, Michael P. Barnes, Christopher Gee and the finder for their input, the University of the Highlands and Islands Archaeology Institute and Orkney Museum for the loan of equipment and access to the artefacts, and editors James Knirk and Henrik Williams and the two anonymous reviewers for their helpful comments. James Knirk also edited the photographs.
}

Futhark 9-10 (2018-2019) 
Lawrence, David. 2005. "An Anthropomorphic Carving from Pictish Orkney." Proceedings of the Society of Antiquaries of Scotland 135: 309-18.

MacGregor, Arthur. 1985. Bone, Antler, Ivory and Horn: The Technology of Skeletal Materials since the Roman Period. London.

Moore, Hazel, and Graeme Wilson. 2011. Shifting Sands: Links of Noltland, Westray: Interim Report on Neolithic and Bronze Age Excavations, 2007-09. Historic Scotland, Archaeology Report 4. Edinburgh.

$\mathrm{OR}+$ no $=$ inscription frtom Orkney published in Barnes and Page 2006.

OR 24 = siglum for the new runic inscription on a spindle whorl from Orkney, devised by the author in accordance with the numbering system in the Scandinavian Runic Text Database.

OR Barnes + no = inscription from Maeshowe on Mainland, Orkney, published in Barnes 1994 (siglum from the Scandinavian Runic Text Database).

Ritchie, Anna. 1971. "Painted Pebbles in Early Scotland." Proceedings of the Society of Antiquaries of Scotland 104: 297-301.

—. 1976-77. "Excavation of Pictish and Viking-Age Farmsteads at Buckquoy, Orkney." Proceedings of the Society of Antiquaries of Scotland 108: 174-227.

Scandinavian Runic Text Database, Department of Scandinavian Languages, Uppsala University (Samnordisk runtextdatabas, Institutionen för nordiska språk, Uppsala universitet). http://www.nordiska.uu.se/forskn/samnord.htm

Sharples, Niall. 1998. Scalloway: A Broch, Late Iron Age Settlement and Medieval Cemetery in Shetland. Cardiff Studies in Archaeology, Oxbow Monograph 82. Oxford.

Smith, Andrea N. 2007. "Worked Bone." In Excavations at Pool, Sanday: A Multiperiod Settlement from Neolithic to Late Norse Times, by John Hunter with Julie M. Bond and Andrea N. Smith, 459-514. Vol. 1 of Investigations in Sanday, Orkney. Kirkwall.

Smith, Beverly B., ed. 1994. Howe: Four Millennia of Orkney Prehistory: Excavations 1978-1982. Society of Antiquaries of Scotland, Monograph ser., 9. Edinburgh.

Thomas, Antonia. 2016. Art and Architecture in Neolithic Orkney: Process, Temporality and Context. Oxford.

Walton Rogers, Penelope. 1997. Textile Production at 16-22 Coppergate. Fasc. 11 of The Archaeology of York, vol. 17: The Small Finds. York. 
